\title{
Soil nitrogen accumulation in fertilized pastures of the Southern Plains
}

\author{
WILLIAM A. BERG
}

\begin{abstract}
Abatract
Marcinal farmlands seeded to grasses in the Southern Great Piain usually have been depleted in $\mathbf{N}$ by cropping, cultivation, and erosion. This study measured soll $N$ accumulation over 20 to 22 years in $\mathbf{N}$ fertilized weeping lovegrass (Eragrostls curvula) or Old World bluestem (Bothriochloa cuucasica) pastures seeded into old nelds as compared to adjacent unfertilized old field pastures dominated by sand dropaced (Sporobolus cryptandrus). Significantly more $(P<0.05)$ total $\mathrm{N}$ was found in the surface $5 \mathrm{~cm}$ of soil from the fertilized pastures. Total $N$ was not dignificantly different between the old field and $\mathbf{N}$ fertilized pastures at greater depths. Two different samplings resulted in an eatimated 8 and $5 \mathrm{~kg} N$ $\mathrm{ha}^{-1} \mathrm{yr}^{-1}$ (standard error of the mean difference 2.4, $\mathrm{n}=4$ and 2.0, $n=10$, respectively) greater $N$ accumulation in the $N$ fertilized pastures as compared to the old field pastures. Nitrogen input into the $N$ fertilized pastures as fertilizer and protein supplement was $45 \mathrm{~kg}$ $\mathrm{N} \mathrm{a}^{-1} \mathrm{yr}^{-1}$ greater than into the old feld pastures. Thus, a relatively small proportion of the $\mathbf{N}$ input into the $\mathbf{N}$ fertilized pasture was accounted for as increased coll $\mathbf{N}$. The $\mathbf{N}$ accumulation rate in the $\mathbf{N}$ fertilized pastures appears to be considerably slower than the $N$ depletion rate under past farmins practices.
\end{abstract}

Key Words: mardinal farmland, warm-season grasses, old fields, grazing

Several million hectares of eroded marginal farmland in the Southern Great Plains have been and are being seeded to grass. Although mixtures of native grasses were commonly used, monocultures of introduced grasses are also used. Weeping lovegrass (Eragrostis curvula (Schrad.)Nees), introduced from Africa, is seeded on sands and loamy sands and Old World bluestems (Bothriochloa spp.), introduced from Asia, are seeded on finer textured soils. Well-managed stands of these introduced grasses have the potential to produce several fold greater beef gains per

\footnotetext{
Author is a soil scientist, South Plains Range Research Station, USDA-ARS, 2000 18th Street, Woodwerd, Okla. 73801.

The work of John Loch in sampling and Linda Bradford and Khaja Khaleeluddin in chemical analysis is gratefully acknowied ged.

Manuscript accepted 3 September 1987.
}

hectare than those produced on native range (Shoop et al. 1976, Rollins and Sims 1985, Dahl and Cotter 1984). Management for this level of beef production on weeping lovegrass or Old World bluestem pastures usually includes spring burning, $\mathrm{N}$ fertilization, and a much higher stocking rate than on native range.

Knowledge of the quantity of soil $\mathbf{N}$ accumulated in $\mathbf{N}$ fertilized pasture seeded into old farmlands will help to predict the fate of $\mathbf{N}$ inputs. This information can also be used to predict the long-term $\mathbf{N}$ requirements of the pastures and the $\mathbf{N}$ resource available if the pastures are returned to cropland.

Soils seeded to grass in the Southern Plains usually have been depleted in $\mathbf{N}$ by cultivation, cropping, and erosion. Thirty-three years of farming reduced total $\mathrm{N}$ in the surface $30 \mathrm{~cm}$ of a sandy loam soil in western Oklahoma from 0.8 down to $0.32 \mathrm{~g} \mathrm{~N} \mathrm{~kg}^{-1}$ (Haas et al. 1957). This is an average loss of $45 \mathrm{~kg} \mathrm{~N} \mathrm{ha}^{-1} \mathrm{yr}^{-1}$ if bulk densities of 1.2 and 1.5 are assumed for the virgin soil and cropped soil, respectively. However, the rate of $\mathbf{N}$ loss is not linear, as Hobbs and Thompson (1971) found much greater average annual loss of soil $\mathrm{N}$ the first 10 to 20 years of cultivation than after 50 to 60 years.

Total $\mathbf{N}$ concentration of soil under improved pastures in South Dakota increased about $0.09 \mathrm{~g} \mathrm{~kg}^{-1}$ in 8 years (White et al. 1976). This is about $22 \mathrm{~kg} \mathrm{~N} \mathrm{ha}^{-1} \mathrm{yr}^{-1}$ if the change occurred in the surface $15 \mathrm{~cm}$ and a bulk density of 1.2 is assumed. Twenty to $25 \mathrm{~kg}$ of $\mathrm{N}$ $\mathrm{ha}^{-1} \mathrm{yr}^{-1}$ accumulated in ungrazed drastically disturbed sites initially very low in total $\mathbf{N}$ in Nebraska (Andrew and Rhoades 1947) and in Saskatchewan (Anderson 1977). Power (1980) states that studies in the Northern Great Plains, "have seldom shown a measureable change in total soil $\mathbf{N}$ content after several years of applying moderate rates of fertilizer $\mathbf{N}$ to perennial grasslands." In areas receiving more precipitation, supporting legumes, or fertilized at higher rates, long-term soil $\mathrm{N}$ accumulation under pastures has been 30 to $100 \mathrm{~kg} \mathrm{~N} \mathrm{ha}^{-1} \mathrm{yr}^{-1}$ (Barrow 1969, Whitehead 1970).

The objective of this study was to measure the change in soil $\mathrm{N}$ over 20 to 22 years in old fields converted to $\mathbf{N}$ fertilized weeping lovegrass and Old World bluestem pastures as compared to unfertilized old field pastures dominated by sand dropseed (Sporobolus cryptandrus (Torr.)Gray). 


\section{Study Area and Methods}

The study location was in Harper County, northwest Oklahoma on the Southern Plains Experimental Range. Average annual precipitation is $590 \mathrm{~mm}$. About $70 \%$ of the precipitation occurs during the frost-free period from mid April to mid October. The soils are mapped as the Pratt series (sandy, mixed, thermic Psammentic Haplustalf). The texture of the surface $15 \mathrm{~cm}$ ranged from sandy loam to loamy sand. Native perennial vegetation on the Pratt soils is dominated by sand bluestem (Andropogon hallii Hack.) sand dropseed, blue grama (Bouteloua gracilis(H.B.K.) Lag.), switchgrass (Panicum virgatum L.), and sand sagebrush (Artemisia filifolia Torr.).

The $1 \times 4 \mathrm{~km}$ study area was initially plowed in about 1900 and farmed for several years and then, because of severe wind erosion, allowed to revegetate naturally. In the 1940 s, the area was again plowed, cropped to sorghum (Sorghum bicolor (L). Moench) for several years, and then seeded to perennial forage species. The success in stand establishment and longevity among species varied. By 1982 when the area was sampled, sand dropseed was the most abundant perennial in the old fields. The perennials, blue grama, sand paspalum (Paspalum stramineum Nash), windmillgrass (Chloris verticillata Nutt., and western ragweed (Ambrosia psilostachya DC.) were common, and japanese brome (Bromus japonicus Thumb.), a naturalized winter annual, was seasonally abundant.

In the late 1950s and early 1960 s monocultures of weeping lovegrass or Old World bluestem (Bothriochloa caucasica (Trin.) Hubb.) were established in portions of the old fields. These 2 to 5 ha pastures have been intensively managed since 1963 (Shoop et al. 1976 , Sims and Dewald 1982), receiving a total of $740 \mathrm{~kg} \mathrm{~N}^{-1}$ as urea (35\% of the $N$ ) and ammonium nitrate over the period 1963 through 1982. An additional $134 \mathrm{~kg} \mathrm{~N} \mathrm{ha}^{-1}(1 / 2$ in urea, $1 / 2$ in $\mathrm{Nh}_{4} \mathrm{NO}_{3}$ ) was added through 1984 . The fertilizer was broadcast annually in the spring at the rate of 28 to $67 \mathrm{~kg} \mathrm{~N} \mathrm{ha}^{-1}$. The mean pH of the surface $5 \mathrm{~cm}$ of soil in 1982 was 6.7 in old fields as compared to 5.3 in the $\mathrm{N}$ fertilized pastures (Berg 1986).

Steers were usually grazed in these pastures from November to early September at one steer per 3.2 ha of old field pasture and one steer per 0.7 ha of $\mathbf{N}$ fertilized pasture. The steers were supplemented during the winter with $41 \%\left(0.41 \mathrm{~kg} \mathrm{~kg}^{-1}\right)$ protein cottonseed cake at the rate of $0.7 \mathrm{~kg} \mathrm{day}^{-1}$ steer $^{-1}$ for about 120 days. Total steer gain was about $55 \mathrm{~kg} \mathrm{ha}^{-1} \mathrm{yr}^{-1}$ on old field pastures and $200 \mathrm{~kg}$ $\mathrm{ha}^{-1} \mathrm{yr}^{-1}$ on $\mathrm{N}$ fertilized pastures. Steers usually weighed about 220 $\mathrm{kg}$ when put into the pastures and gained about $180 \mathrm{~kg}$ on old field pastures and $140 \mathrm{~kg}$ on fertilized pastures. Weeping lovegrass pastures were usually hayed in late spring and the hay fed within the pastures the following winter. The $\mathrm{N}$ fertilized pastures were burned each spring that enough residue was present to carry a fire, an estimated 1 in 2 years. The old field pastures were not burned or fertilized.

The initial soil sampling in October 1982 was on 4 sites, each extending from an old field pasture into a $\mathrm{N}$ fertilized pasture. Two of the $\mathbf{N}$ fertilized pastures were in weeping lovegrass and 2 in Old World bluestem. It was assumed that each site was once a common field before establishment of the introduced grass. Each site of approximately 2 ha was selected for uniform topography and soils within the site. Soil cores, $4.1 \mathrm{~cm}$ in diameter, were taken from 10 random locations within each pasture on each site. Cores were divided by $5-\mathrm{cm}$ increments to a depth of $20 \mathrm{~cm}$ and then by $10-\mathrm{cm}$ increments to $80 \mathrm{~cm}$. Each core sample was handled as an individual sample on which total $\mathrm{N}$, exchangeable $\mathrm{NH}_{4}{ }^{+}-\mathrm{N}$, and $\mathrm{NO}_{3}-\mathrm{N}$ were determined.

A second soil sampling was made in November 1984 in an attempt to more precisely quantify $\mathrm{N}$ accumulation. Ten sites of approximately 0.1 ha each extending from an old field pasture into a $\mathbf{N}$ fertilized pasture were sampled. Within each pasture on each of these sites twenty 2-cm diameter soil cores to a depth of 20-cm were randomly taken. Cores were divided into $5-\mathrm{cm}$ increments and increments were composited from a given depth within each pas- ture. In this sampling 6 of the $\mathbf{N}$ fertilized pasture sites were in weeping lovegrass and 4 were in Old World bluestem. The 4 sites sampled in 1982 were included in the 10 sites sampled in 1984 . Sites sampled in 1984 were smaller, a reflection of the difficulty in locating 10 visually uniform sites in 7 different $\mathbf{N}$ fertilized pastures and associated old field pastures. Depth of surface darkening and Munsell colors of the darkened zone and of soil below the darkened zone were determined on 10 separate cores taken from each $\mathbf{N}$ fertilized pasture sampled in 1984.

Sampling locations were at least $10 \mathrm{~m}$ from the common fence between old field and $\mathbf{N}$ fertilized pastures. Each site sampled was at least $200 \mathrm{~m}$ from other sample sites. Soil samples were not taken from within the basal area of weeping lovegrass or Old World bluestem plants. Soil samples were air dried and then screened through a sieve with 2-mm openings. Gravel, which ranged from 0 to $3 \%$ of the sample mass, was discarded. Roots in soil samples were crushed against the screen and included in the soil samples.

Soil bulk density was measured by $5-\mathrm{cm}$ increments to $15 \mathrm{~cm}$ by the excavation method near each sampling point in the initial sampling (October 1982), and at 5 random locations within each pasture on each site at the second sampling (November 1984). No statistically significant differences were found in bulk densities within a given depth between old field and $\mathbf{N}$ fertilized pastures. Mean bulk density of each depth increment for each pasture for each sampling within a site was used to calculate total N, organic C, exchangeable $\mathrm{NH}_{4}^{+}-\mathrm{N}$, and $\mathrm{NO}_{3}-\mathrm{N}$ mass. Bulk density of soil samples taken from deeper than $15 \mathrm{~cm}$ was assumed to be $1.5 \mathrm{~g}$ $\mathrm{cm}^{-5}$, which was the measured mean bulk density of the 5 to $15-\mathrm{cm}$ increments.

Standing dead vegetation on the four 2-ha sites was determined in March 1984 by clipping all herbage at a $1-\mathrm{cm}$ height within each of 10 randomly placed $1 / 2-m^{2}$ quadrats in each pasture. Feces were collected from 40 randomly placed $1 / 2 \mathrm{~m}^{2}$ quadrats in each pasture on each site. Feces were dried at $60^{\circ} \mathrm{C}$, ground, and total $\mathrm{N}$ determined by the method given below for soil.

Total $\mathbf{N}$ was determined by a micro-kjeldahl procedure in which 4-g soil samples were digested and the ammonium in the digest determined by the indophenol blue method (Dorich and Nelson 1983). Ammonium-N in 2 M KCL extracts was determined by the indophenol blue method. Nitrate-N extracted with water was determined by the chromotropic acid method (Soltanpour and Workman 1981). Organic $C$ was determined by the modified Mebius method (Nelson and Sommers 1982) on soil samples taken in 1984.

Analysis of variance, using sites as randomized blocks, was used for each soil depth increment to determine treatment effects on total $\mathrm{N}$, organic $\mathrm{C}$, exchangeable $\mathrm{NH}_{4}{ }^{+}-\mathrm{N}$, and $\mathrm{NO}_{3}-\mathrm{N}$ in soil samples.

\section{Results and Discussion}

Total soil $\mathbf{N}$ was greater in the surface $5 \mathrm{~cm}$ of $\mathrm{N}$ fertilized pastures than in old field pastures for the 1982 sampling (Table 1). Total $\mathbf{N}$ was not significantly different between $\mathrm{N}$ fertilized and old field pastures at greater depths. Exchangeable $\mathrm{NH}_{4}{ }^{+}-\mathrm{N}$, and $\mathrm{NO}_{3}{ }^{-}$ $\mathbf{N}$ were greater in the surface $10 \mathrm{~cm}$ of $\mathbf{N}$ fertilized pasture than in old field pastures (Tables 2,3), however, quantities were very small in relation to total $\mathbf{N}$ (Table 1).

In 1984, sampling was expanded to 10 sites in an effort to more precisely quantify the amount of $\mathrm{N}$ in the surface $20 \mathrm{~cm}$. In 1984 sampling, as in the 1982 sampling, the only significantly greater amount of total $\mathbf{N}$ was in the surface $5 \mathrm{~cm}$ of $\mathrm{N}$ fertilized pastures as compared to old field pastures (Table 4). Amounts of exchangeable $\mathrm{NH}_{4}{ }^{+}-\mathrm{N}$, and $\mathrm{NO}_{3}-\mathrm{N}$ found in 1984 (Table 4) were greater than those found in 1982 (Tables 2,3), but were still small in relation to total $\mathbf{N}$.

In addition to total $\mathrm{N}$ in soil, other pasture components containing $\mathrm{N}$ include; standing vegetation (standing crop + standing dead), 
Table 1. Total nitrogen in grazed old neld and $\mathbf{N}$ fertilized pastures sampled in $1982(n=4)$.

\begin{tabular}{|c|c|c|c|c|}
\hline Depth & $\begin{array}{l}\text { Old Field } \\
\text { Pastures }\end{array}$ & $\begin{array}{l}\text { N Fertilized } \\
\text { Pastures }\end{array}$ & $\begin{array}{l}\text { Std. error of } \\
\text { mean difference }\end{array}$ & $\begin{array}{c}\text { Probability } \\
\text { of }>F\end{array}$ \\
\hline $\mathrm{cm}$ & & $-\mathrm{g} \mathrm{N} \mathrm{m}^{-2}$ & & \\
\hline $0-5$ & 53.5 & 69.4 & 4.8 & 0.05 \\
\hline $5-10$ & 37.6 & 36.9 & 3.8 & 0.86 \\
\hline $10-15$ & 31.6 & 33.7 & 2.7 & 0.48 \\
\hline $15-20$ & 32.5 & 32.2 & 2.3 & 0.92 \\
\hline $20-30$ & 61.0 & 63.9 & 3.6 & 0.47 \\
\hline $30-40$ & 51.8 & 54.4 & 4.1 & 0.56 \\
\hline $40-50$ & 49.3 & 50.7 & 5.8 & 0.83 \\
\hline $50-60$ & 39.8 & 44.8 & 3.2 & 0.21 \\
\hline $60-70$ & 35.9 & 39.2 & 4.8 & 0.54 \\
\hline $70-80$ & 30.2 & 34.6 & 4.0 & 0.35 \\
\hline
\end{tabular}

Table 2. Exchangeable $\mathrm{NH}_{4}^{+}-\mathrm{N}$ in grazed old field and $\mathbf{N}$ fertilized pastures sampled in $1982(n=4)$.

\begin{tabular}{lcccc}
\hline \hline Depth & $\begin{array}{c}\text { Old Field } \\
\text { Pastures }\end{array}$ & $\begin{array}{c}\text { N Fertilized } \\
\text { Pastures }\end{array}$ & $\begin{array}{c}\text { Std. error of } \\
\text { mean difference }\end{array}$ & $\begin{array}{c}\text { Probability } \\
\text { of }>\text { F }\end{array}$ \\
\hline $\mathrm{cm}$ & & $0.3 \mathrm{~N} \mathrm{~m}^{-2}$ & & \\
$0-5$ & 0.11 & 0.32 & 0.07 & 0.05 \\
$5-10$ & 0.07 & 0.13 & 0.02 & 0.04 \\
$10-15$ & 0.06 & 0.08 & 0.01 & 0.09 \\
$15-20$ & 0.08 & 0.07 & 0.01 & 0.23 \\
$20-30$ & 0.12 & 0.18 & 0.01 & 0.01 \\
$30-40$ & 0.12 & 0.17 & 0.01 & 0.01 \\
$40-50$ & 0.13 & 0.18 & 0.01 & 0.01 \\
$50-60$ & 0.13 & 0.18 & 0.02 & 0.06 \\
$60-70$ & 0.13 & 0.16 & 0.01 & 0.07 \\
$70-80$ & 0.12 & 0.15 & 0.01 & 0.11 \\
\hline
\end{tabular}

Table 3. Nitrate- $\mathbf{N}$ in grazed old field and $\mathbf{N}$ fertilized pastures sampled in $1982(n=4)$.

\begin{tabular}{lcccc}
\hline \hline Depth & $\begin{array}{c}\text { Old Field } \\
\text { Pastures }\end{array}$ & $\begin{array}{c}\text { N Fertilized } \\
\text { Pastures }\end{array}$ & $\begin{array}{c}\text { Std. error of } \\
\text { mean difference }\end{array}$ & $\begin{array}{c}\text { Probability } \\
\text { of }>\text { F }\end{array}$ \\
\hline cm & & -8 N m$^{-2}$ & & \\
$0-5$ & 0.19 & 0.49 & 0.07 & 0.02 \\
$5-10$ & 0.09 & 0.21 & 0.03 & 0.03 \\
$10-15$ & 0.09 & 0.14 & 0.04 & 0.31 \\
$15-20$ & 0.10 & 0.13 & 0.01 & 0.09 \\
$20-30$ & 0.17 & 0.19 & 0.01 & 0.71 \\
$30-40$ & 0.16 & 0.17 & 0.05 & 0.78 \\
$40-50$ & 0.17 & 0.22 & 0.08 & 0.57 \\
$50-60$ & 0.15 & 0.23 & 0.10 & 0.49 \\
$60-70$ & 0.14 & 0.22 & 0.11 & 0.52 \\
$70-80$ & 0.11 & 0.27 & 0.10 & 0.20 \\
\hline
\end{tabular}

feces, litter, and crowns of weeping lovegrass and Old World bluestem. Amount of standing vegetation in the pastures varied with species, intensity of grazing, and season of sampling. Standing vegetation measured on 2 March 1984 was 54 and $52 \mathrm{~g} \mathrm{~m}^{-2}$ for old field and $\mathrm{N}$ fertilized pastures, respectively (standard error of mean difference $=4 \mathrm{~g} \mathrm{~m}^{-2}, \mathrm{n}=4$ ). Assuming a $\mathrm{N}$ concentration of $6 \mathrm{mg} \mathrm{g}^{-1}$ (Savage and Heller 1947) for the dormant warm-season grasses gives an estimated $\mathrm{N}$ mass of $0.3 \mathrm{~g} \mathrm{~m}^{-2}$. This is a very small amount of $\mathbf{N}$ in relation to total $\mathbf{N}$ in the soil (Tables 1 and 4).

Feces on the soil surface contained 0.5 and $0.9 \mathrm{~g} \mathrm{~N} \mathrm{~m}^{-2}$ for old field and $\mathrm{N}$ fertilized pastures, respectively; the standard error of the mean difference was $0.17 \mathrm{~g} \mathrm{~N} \mathrm{~m}^{-2}(\mathrm{~N}=4)$. An even greater proportion of feces $\mathrm{N}$ in fertilized pastures was expected since the
Table 4. Total $\mathrm{N}$, orzanic $\mathrm{C}$, exchangeable $\mathrm{NH}_{4}{ }^{+}-\mathrm{N}$, and $\mathrm{NO}_{3}-\mathrm{N}$ in grazed old field pastures and $N$ fertilized pastures anmpled in 1984 $(\mathbf{n}=10)$.

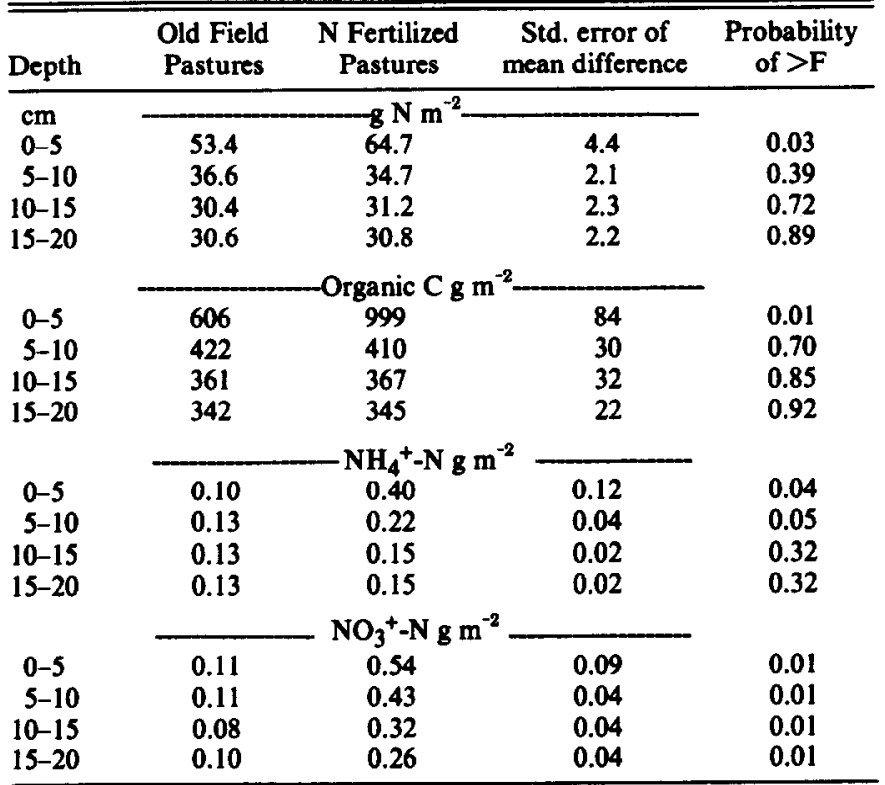

stocking rate was 0.7 ha steer ${ }^{-1} \mathrm{yr}^{-1}$ in these pastures as compared to 3.2 ha steer $^{-1} \mathrm{yr}^{-1}$ in old field pastures. Possibly, burning and greater $\mathrm{N}$ availability for feces decomposition in $\mathrm{N}$ fertilized pastures kept the proportion of feces $\mathbf{N}$ lower than might be expected from the higher stocking rate.

Litter was not measured in this study, but the amount was small in old field pastures and accumulation in $\mathbf{N}$ fertilized pastures was burned as part of the overall pasture management. Crowns of weeping lovegrass and Old World bluestem would add to total $\mathrm{N}$ in $\mathrm{N}$ fertilized pastures; however, no estimate of this $\mathbf{N}$ was obtained in this study. Overall, $\mathbf{N}$ in standing dead vegetation, feces, litter, and crowns of weeping lovegrass and Old World bluestem was assumed to be small in relation to soil $\mathrm{N}$.

Total soil $\mathrm{N}$ in $\mathrm{N}$ fertilized pastures was $15.9 \mathrm{~g} \mathrm{~N} \mathrm{~m}^{-2}$ greater than in old fields for the 0-5 cm depth in the 1982 sampling (Table 1). This is an estimate of $\mathbf{N}$ accumulated from $\mathbf{N}$ fertilizer plus $\mathbf{N}$ in protein supplement in excess of that fed in old field pastures. Converting this estimate of $\mathrm{N}$ accumulation to $\mathrm{kg} \mathrm{ha}^{-1}$ on an annual basis gives $8 \mathrm{~kg} \mathrm{~N}$ accumulation $\mathrm{ha}^{-1} \mathrm{yr}^{-1}$ for the 1982 sampling. The standard error of the mean difference is $2.4 \mathrm{~kg} \mathrm{~N} \mathrm{ha}^{-1} \mathrm{yr}^{-1}$. With application of a $95 \%$ confidence interval, this gives a range of 0.3 to $16 \mathrm{~kg} \mathrm{~N}$ accumulated $\mathrm{ha}^{-1} \mathrm{yr}^{-1}$. The $\mathrm{N}$ accumulation calculated from the 1984 sampling (Table 4) was $5 \mathrm{~kg} \mathrm{~N} \mathrm{ha}^{-1} \mathrm{yr}^{-1}$, with a $95 \%$ confidence interval of 0.6 to $9.7 \mathrm{~kg} \mathrm{~N} \mathrm{ha}^{-1} \mathrm{yr}^{-1}$. It is disappointing that $\mathbf{N}$ accumulation in soil of $\mathbf{N}$ fertilized pastures as compared to old field pastures could not be more precisely quantified. However, results of the 1982 and 1984 samplings are in general agreement that $\mathrm{N}$ accumulation over 20 to 22 years in $\mathrm{N}$ fertilized pastures is one third or less of estimated $\mathbf{N}$ input into $\mathbf{N}$ fertilized pastures minus estimated $\mathrm{N}$ input into old field pastures (Table 5).

Organic $\mathbf{C}$ in the surface $5-\mathrm{cm}$ of $\mathbf{N}$ fertilized pastures was significantly greater than in old field pastures (Table 4). There were no significant differences in organic $\mathbf{C}$ at greater depths. Darker surface soils were observed to a mean depth of $1.6 \mathrm{~cm} \pm 0.14$ (std error) in $\mathbf{N}$ fertilized pastures. Moist soil color of the darker surface was $10 \mathrm{YR} 3 / 3$ on most samples, and $10 \mathrm{YR} 3 / 2$ and $2 / 2$ on some samples. The demarcation from the darkened surface to the underlying soil (10 YR 4/4, moist) was distinct. Surface darkening was not obvious in the old field pastures. The mean $\mathrm{C} / \mathrm{N}$ ratio in the surface 5 -cm of soil from old field pastures was 11.4 as compared to 
Table 5. Estimated annual nitrozen inputs into old field and $\mathbf{N}$ fertilized pastures.

\begin{tabular}{lcc}
\hline \hline N Source & Old Field Pastures N Fertilized Pastures \\
\hline Precipitation $^{1}$ & 7 & 7 \\
Dry fallout $^{2}$ & 1 & 1 \\
Protein supplement $^{3}$ & 2 & 8 \\
N Fertilizer $^{-3}$ & 0 & 39 \\
Other $^{4} \quad$ & - & - \\
\multicolumn{1}{c}{ Total } & 10 & 55 \\
\hline
\end{tabular}

${ }_{1}^{1}$ Measured at Woodward, OK, Sharpley, et al. 1985.

2Estimated

3Known mean annual inputs.

There is no estimate available for biological $\mathrm{N}_{2}$ fixation in these pastures, there are no legumes present, biological fixation is assumed to be low.

15.4 for $\mathbf{N}$ fertilized pastures (calculated from data in Table 4 ). The distinct surface darkening and the relatively wide $\mathrm{C} / \mathrm{N}$ ratio may be associated with pasture burning.

Overall, the study indicates $\mathbf{N}$ is accumulating in the $\mathbf{N}$ fertilized pastures, but the accumulation rate appears to be much slower than the depletion rate under past farming practices (Haas et al. 1957, Hobbs and Thompson 1971). The limited amount of $\mathbf{N}$ accumulation indicates that there was substantial $N$ loss from the $\mathrm{N}$ fertilized pastures. Only about $5 \mathrm{~kg} \mathrm{~N} \mathrm{ha}^{-1} \mathrm{yr}^{-1}$ can be allocated to removal as beef gain. Other $\mathbf{N}$ losses were probably as ammonia volatilized from urine, feces, and senescing vegetation (Woodmansee 1978, Vallis et al. 1985 Schimel et al. 1986). Burning of the fertilized pastures also resulted in $\mathrm{N}$ loss. Sharrow and Wright (1977) reported $87 \% \mathrm{~N}$ loss from litter and old growth after burning a dense stand of tobosagrass (Hilaria mutica, Benth.) in the rolling plains of Texas. A 48-year study on bluestem range found soil $\mathbf{N}$ was decreased in ungrazed pasture by annual burning (Owensby and Wyrill 1973). A 20-year study on grazed pastures found less soil $\mathbf{N}$ in late spring burned pastures than in unburned pastures, however, soil $\mathbf{N}$ was not significantly different in early and mid spring burned pastures than unburned pastures (Owensby and Wyrill 1973). Burning raises spring soil temperatures and increases the rate of organic matter breakdown (Wright 1986). Thus, burning may arrest organic matter accumulation. Some ammonia volatilization from broadcast urea applications probably occurred (Berg and Coyne 1983). Some $\mathbf{N}$ may be lost by leaching since there is groundwater recharge from extensive areas of sandy soils in northwest Oklahoma. A more complete characterization of the fate of $\mathbf{N}$ added to these and similar grazing systems requires the identification and quantification of $\mathrm{N}$ loss pathways.

\section{Literature Cited}

Anderson, D.W. 1977. Early stages of soil formation on glacial till mine spoils in a semi-arid climate. Geoderma 19:11-19.

Andrew, L.E., and H.F. Rhoudes. 1947. Soil development from calcareous glacial material in eastern Nebraska during seventy-five years. Soil Sci. Soc. Amer. Proc. 12:407-408.

Barrow, N.J. 1969. The accumulation of soil organic matter under pasture and its effect on soil properties. Aust. J. Exp. Agr. and Anim. Husb. 9:437-444.

Ber, W.A. 1986. Effect of 20 years of low $\mathrm{N}$ rate pasture fertilization on soil acidity. J. Range Manage. 39:122-124.
Bers, W.A. and P.I. Coyne. 1983. Fertilization and water use of improved pasture grasses in western Oklahoma and adjacent areas in Texas. p. 26-35. In: Proceedings range and pasture seeding in the Southern Great Plains. Texas A\&M Univ. Agr. Res. Center, Vernon.

Dahl, B.E. and P.F. Cotter. 1984. Management of weeping lovegrass in west Texas. Range and Wildlife Management Note 5, College of Agricultural Science, Texas Tech Univ., Lubbock.

Dorich, R.A. and D.W. Nelson. 1983. Direct colorimetric measurement of ammonium in potassium chloride extracts of soils. Soil Sci. Soc. Amer. J. 47:833-836.

Hans, H.J., C.E. Evans, and E.F. Miles. 1957. Nitrogen and carbon changes in Great Plains soils as influenced by cropping and soil treatments. USDA Tech. Bull. 1164.

Hobbs, J.A., and C.A. Thompson. 1971. Effect of cultivation on the nitrogen and organic carbon contents of a Kansas Argiustoll (Chemozem) Agron. J. 63:66-68.

Nelson, D.W. and L.E. Sommers. 1982. Total carbon, organic carbon, and organic matter. In: A.L. Page (ed.) Methods of Soil Analysis, Part 2, second edition. Agronomy 9:539-579. Amer. Soc. of Agron., Madison, Wis.

Owenby, C.E., and J.B. Wyrill, III. 1973. Effects of range burning on Kansas Flint Hills soils. J. Range Manage. 26:185-188.

Power, J.F. 1980. Response of semiarid grassland sites to nitrogen fertilization: II. Fertilizer recovery. Soil Sci. Soc. Amer. J. 44:550-555.

Rollins, D., and P.L. Sims, 1985. Beef production from Old World bluestems. Cooperative Extension Service, OSU Ext. Fact No. 3020. Oklahoma State Univ., Stillwater.

Savaze, D.A., and V.G. Heller. 1947. Nutritional qualities of range forage plants in relation to grazing with beef cattle on the Southern Plains Experimental Range. USDA Tech. Bull. 943.

Schimel, D.S., W.J. Parton, F.J. Adamsen, R.G. Woodmansee, R.L. Senft, and M.A. Stillwell. 1986. The role of cattle in the volatile loss of nitrogen from a shortgrass steppe. Biogeochemistry 2:39-52.

Sharpley, A.N., S.J. Smith, R.G. Menxel, and R.L. Weaterman. 1985. The chemical composition of rainfall in the southern plains and its impact on soil and water quality. Tech. Bull. T-162, Agr. Exp. Sta. Oklahoma State Univ., Stillwater.

Sharrow, S.H., and H.A. Wright. 1977. Effects of fire, ash, and litter on soil nitrate, temperature, moisture, and tobosagrass production in the rolling plains. J. Range Manage. 30:266-270.

Shoop, M., E.H. Mellvain, and P.W. Voight. 1976. Morpa weeping lovegrass produces more beef. J. Range Manage. 29:101-103.

Sims, P.L., and C.L. Dewald. 1982. Old World bluestems and their forage production potential for the Southern Great Plains. USDA-ARS ARM-S-28.

Soltanpour, P.N., and S.M. Workman. 1981. Soil-testing methods used at Colorado State University Soil Testing Laboratory. Colorado State Univ. Exp. Sta. Tech. Bull. 142, Fort Collins.

Vallis, I., D.C.I. Peake, R.K. Jones, and R.L. MeCown. 1985. Fate of urea-nitrogen from cattle urine in a pasture-crop sequence in a seasonally dry tropical environment. Aust. J. Agr. Res. 36:809-817.

White, E.M., C.R. Kruezer, and R.A. Moore. 1976. Changes in total N, organic matter, available $P$, and bulk densities of a cultivated soil 8 years after tame pastures were established. Agron. J. 68:581-583.

Whitehead, D.C. 1970. The role of nitrogen in grassland productivity. Commonwealth Bureau of Pastures and Field Crops, Bull. 48. Commonwealth Agr. Bur., Bucks, England.

Woodmansee, R.G. 1978. Additions and losses of nitrogen in grassland ecosystems. Bioscience. 28:448-453.

Wright, H.A. 1986. Manipulating rangeland ecosystems with fire. p. 3-6. In: Prescribed fire and smoke management symposium proceedings. February 13, 1986, Kissimee, Florida. Society for Range Management, Denver. 